\title{
Journals lack explicit policies for separating eds from ads
}

\section{Jim Giles, London}

Two in five biomedical journals have no declared policy on how to separate editorial and commercial matters, according to the preliminary results of a survey of editors.

Some journal editors say they find the results disturbing, given the commercial pressure that journals have to deal with. Many say they have experienced cases where companies have sought, to varying degrees, to influence journal content.

The survey asked the 350 members of the Committee on Publication Ethics (COPE), a London-based association of journal editors and publishers, whether their employers had a "declared policy on how to ensure a separation between editorial and commercial decisions". The 118 responses received by 11 March indicate that $39 \%$ of respondents' journals had no such policy.

Reprints are one area in which editorial and financial issues can become entangled, says Alex Williamson, publishing director at the BMJ (formerly British Medical Journal) Publishing Group in London. She has seen submission letters in which authors claimed that, should the paper involved be accepted, a pharmaceutical company would buy large numbers of reprints. "That can be verylucrative for the journal,"Williamson says.

Some editors argue that formal policies are required to help them fend off more subtle attempts from companies to influence their content. "It doesn't have to be direct," agrees Merrill Goozner, director of the Integrity in Science project at the Center for Science in the Public Interest in Washington DC. "It can be implied."

And editors warn of the dangers of approaching firms with offers to sell adverts next to papers about the product being advertised, a practice that many publications have policies against. "I know other journals do this," Williamson says. "That can put editors under pressure."

Some journals, including the medical giants such as the $B M$ J and The Lancet, check the factual content of the adverts that they run. But smaller journals often lack the resources to make such checks, say COPE members. A senior staff member at one journal that does check - who asked not to be named says that he asks for changes to be made to one in every three adverts submitted to his publication. Monitoring often uncovers the use of references that do not back up the claims made in the advert, he says, adding that the process is "very labour intensive".

Public rows between sponsors and journals may also put pressure on editors. In 2000, the house journal of the Hastings Center, a bioethics research institute in Garrison, New York, published a critical article on antidepressant drugs by David Healy, a director of psychological medicine at the University of Cardiff, Wales. A few months after publication, pharmaceutical manufacturer Eli Lilly withdrew its annual $\$ 25,000$ grant to the centre, saying that the Healy article was "inaccurate and unbalanced".

Some editors fear that such incidents could make journals think twice before publishing material attacking pharmaceutical or other industries. To provide editors with support if they feel under pressure, COPE members suggest that journals produce policies that cover relationships with advertisers, sponsors and firms involved in any other revenue streams. The policies would stress that issues such as reprint sales should not influence the peer-review process and that adverts should be checked for accuracy.

But some publishing insiders suggest that the $39 \%$ figure may overstate the problem. "The policies may not be explicit, but they are almost a given at most organizations," says Andrea Powell, chair of the Association of Learned and Professional Society Publishers, based in Worthing, West Sussex. "Editors are not likely to be swayed, as they don't want their objectivity thrown into doubt."

www.publicationethics.org.uk
WWF warns that China's forests are not out of the woods

Rachael Williams, Tokyo

Government incentives to restore tree cover in China have damaged the environment and levied a high cost on forests worldwide, according to a WWF report issued this March. The critique suggests that China is shifting the ecological burden of its industrialization on to other countries.

China has been keen to impose logging bans and promote replanting schemes since floods in 1998 killed thousands of people and inundated millions of hectares of farmland. The conservation group WWF has largely approved of these policies, particularly as they expand the habitat of the endangered giant panda.

But, although official statistics show that the total amount of forest in China has increased by $1.2 \%$ a year over the past decade, much of the restored forest consists of single-species plantations on previously non-forested land, says the WWF report. As logging of some natural forest continues, this means that China's forest diversity is probably declining, it says.

As its housing and energy needs grow, China continues to be one of the world's largest importers of illegally logged wood. To fill the gap between supply and demand it is estimated that China will need to import 125 million cubic metres of wood in the year 2010. More than half of this will probably come from Russia, Indonesia and Malaysia, where logging is poorly regulated.

Illegal logging in such countries has long been seen as an important international issue. At an 18 March prelude to the G8 summit due to be held in Scotland this July, environmental and development ministers from the world's eight leading industrialized nations committed to voluntary measures to address the problem. But environmental groups criticized the pledge, saying that legislative actions are needed. They added that countries outside the G8 particularly China - also need to make responsible decisions about the resources they need.

David Kaimowitz, director of the Center for International Forestry Research, based in Indonesia, says it is China's ultimate aim to get most of its forestry products from its own plantations. "But no one knows when this will happen, if ever," he says. "For the sake of the world's forests, let us hope it does."
Book worms: advertisers can put editors under pressure. 